\title{
Sharing housework between husbands and wives: how to improve marital satisfaction for working wives in Japan
}

\author{
Mayu Kobayashi ${ }^{1}$, Miki Kobayashi ${ }^{2}$, Tsunao Okumura ${ }^{3}$ and Emiko Usui ${ }^{4^{*}}$ (D)
}

\author{
* Correspondence: \\ usui@ier.hit-u.ac.jp \\ ${ }^{4}$ Institute of Economic Research, \\ Hitotsubashi University and IZA, \\ Tokyo 186-8603, Japan \\ Full list of author information is \\ available at the end of the article
}

\begin{abstract}
This paper examines whether and how the marital satisfaction of Japanese couples is related to the housework the spouse performs. For single-earner couples, both husbands and wives are more satisfied with the other spouse if the wife performs the greater share of the housework on weekdays. In dual-earner couples, both husbands and wives experience higher spousal satisfaction when the other spouse performs more housework on weekdays. Japanese dual-earner couples are unable to spend more time on housework, because wives are already performing a significant share of housework on weekdays while husbands are working long hours.
\end{abstract}

JEL Classification: J12, J22

Keywords: Marriage, Housework/division of labor, Satisfaction, Time use, Wives' employment

\section{Introduction}

In Japan, household chores and child-rearing duties are rarely outsourced; family members, particularly women, overwhelmingly perform them (Davis and Greenstein 2004; Greenstein 2009; Kamo 1994). This is the case partly because outside help is not affordable for many families in Japan, unlike in the US and many Asian countries, where hiring domestic workers (often, if not typically, foreign workers) is an affordable and available option (Cortes and Pan 2013; Cortes and Tasseda 2011). In a 2013 survey, only $1.1 \%$ of Japanese households reported having utilized housekeeping services within the past 2 years (Japan Institute for Labour Policy and Training 2014). Furthermore, in a public opinion poll conducted by the Japanese Cabinet Office in 2000, $83.0 \%$ (80.6\%) of Japanese women (men) preferred family members to perform housework-such as meal preparation, cleaning, and washing-whereas only $17.8 \%$ (14.2\%) of women (men) preferred to use outside services for such tasks (Cabinet Office, Government of Japan 2001). Most childcare services in Japan are institutional, and informal babysitting is not common. It is not common practice for older school-aged girls to provide inexpensive babysitting for other families (Aoki 2012) or for immigrant labor to provide inexpensive childcare in the home. Performing household chores and child-rearing on weekdays is a significant burden for working married women because such housework must be performed before or after their workday. If they continue to

(c) 2016 The Author(s). Open Access This article is distributed under the terms of the Creative Commons Attribution 4.0 International License (http://creativecommons.org/licenses/by/4.0/), which permits unrestricted use, distribution, and reproduction in any medium, provided you give appropriate credit to the original author(s) and the source, provide a link to the Creative Commons license, and indicate if changes were made. 
work, these women typically reduce the time they spend on leisure and sleep, which can reduce life satisfaction. Fearing such burdens and given the difficulty faced in engaging in household chores and/or child-rearing while remaining fully employed, many married Japanese women choose to either work part-time at a reduced wage or leave the labor force altogether. In fact, the proportion of married women in Japan who work full-time has remained stagnant, at approximately $30 \%$ since the 1980s (Abe 2011).

Due to Japan's low birthrate and extended life expectancy, the National Institute of Population and Social Security Research (2012) projects that the proportion of the Japanese working-age population (aged between 15 and 64 years) will decrease from its 2010 share of 63.8 to $49.7,50.7$, or $51.9 \%$ by 2060 , depending on whether the projections for both fertility and mortality rates are low, medium, or high, respectively. No matter the scenarios, these demographic projections indicate that the working-age population will continue to decline. One of the most effective ways for Japan to mitigate the adverse effects of this demographic trend is to increase the number of Japanese women participating in the labor market as well as the extent of each woman's participation.

Our paper thus examines how martial satisfaction of Japanese wives is related to the housework that is performed by the husbands. We focus on the nature of the support married men provide by performing household chores. Specifically, we examine whether the timing of housework performed by husbands-on weekdays or weekend$\mathrm{s}$-affects wives' satisfaction with their husbands. We distinguish between weekdays and weekends because the opportunity cost of not working in the market on weekdays is often greater for husbands than for wives, as the market wage of husbands tends to be higher. However, the opportunity cost of not working on weekends tends to be similar for husbands and wives because work opportunities on weekends are similarly limited for both. ${ }^{1}$

Using the Japanese Longitudinal Survey on Employment and Fertility (LOSEF), we find that in couples with a nonworking wife, the wife's satisfaction with her husband is higher when he performs less housework on weekdays, while the husband's satisfaction with his wife is higher when she performs more housework on weekdays. As a result, for single-earner couples, both husbands and wives are more satisfied with the other spouse if the wife performs the greater share of the housework on weekdays. However, in dual-earner couples, spousal satisfaction for both husbands and wives is higher when the other spouse performs more housework on weekdays. Japanese dual-earner couples are unable to spend more time on housework, because of husbands' inability to reduce their long working hours and the fact that wives are already performing a significant share of housework on weekdays. Therefore, institutional and social constraints have to be relaxed to improve the well-being of Japanese dual-earner couples. ${ }^{2}$

The remainder of this paper proceeds as follows. Section 2 describes the LOSEF data. Section 3 discusses how housework is shared among married couples in Japan. The focus of the paper is in Section 4, in which the relationship between the spouse's share of housework and spousal satisfaction is examined. The paper concludes in Section 5.

\section{Data}

We use the 2012 and 2014 waves of the LOSEF, which is administered as a project of the Economic Analysis of Intergenerational Issues and is funded through a Grant-in- 
Aid for Specially Promoted Research from the Japanese Ministry of Education, Culture, Sports, Science and Technology. With assistance from Intage, Inc., the first wave of the survey was administered in 2012, and the second wave was administered in 2014. The survey targeted men and women between 20 and 50 years of age living in Japan in 2012. The survey respondents, who were publicly recruited by Intage, Inc., were randomly stratified based on (i) age, gender, and regional information from the 2010 Census and (ii) the employment to nonemployment ratio from the 2007 Employment Status Survey. The total sample consists of 7114 respondents, of which 2203 are married women and 1980 are married men in the first wave of the sample.

Among the wide range of questions asked of the LOSEF respondents, those that are relevant to this study concern (1) satisfaction with their spouse and (2) the share of housework performed by the respondents and their spouse on weekdays and weekends. Regarding the former, the LOSEF specifically asks, "How satisfied are you with your spouse? Please answer by using the following scale from one to six, one being 'completely unhappy' and six being 'completely happy." 3 Regarding the latter, the LOSEF specifically asks, "In your current household, approximately what percentage of household chores (e.g., child care, cooking, cleaning, and yard work) are taken on by (i) yourself, (ii) your spouse/partner, and (iii) other family/household member(s). Percentages should sum to 100." This questionnaire is adapted from Goldin and Katz's (2008) questionnaire but asks the respondents to provide separate answers to this question for weekdays and weekends. In Japan, the other family members mentioned by married women include children more often than respondents' parents/stepparents and/or respondents' siblings because $85.1 \%$ of married women in the LOSEF sample live with their children, whereas only $14.7 \%$ of married women live with their parents/stepparents and/or their siblings. The rarity of outsourcing housework in Japan is shown by the fact that only $0.78 \%$ of the LOSEF sample reports using housecleaning services more than once a year.

It is important to investigate whether we obtain different results when respondents are asked to report percentages of housework performed (i.e., the respective share of each spouse), as the LOSEF does, and when they are asked to report the amount of housework performed in minutes, as in the case of time-use surveys. We examine this issue by comparing the LOSEF data to the data obtained in the Japanese Panel Survey on Consumers (JPSC), a time-use survey that asks each wife to report the amount of housework in minutes that she and her husband performed (along with many other daily activities). According to Ueda (2005), wives in the JPSC report that they perform $462.1 \mathrm{~min}$ of housework per weekday on average, while husbands perform 37.1 min of housework per weekday on average. Thus, the husband's percentage share of housework on weekdays as reported by his wife is $8.0 \%$. In the LOSEF, which directly asked about the percentage share of housework performed, the husband's share of housework on weekdays as reported by his wife is $9.3 \%$, which is close to the percentage derived from the JPSC. We therefore observe that similar percentages are obtained (i) when the percentage shares of housework are directly asked for and (ii) when the percentages are derived instead from the number of minutes that wives report for their own and their husband's performance of housework. Reporting "shares" of housework (by percentages) thus appears to be as effective a method of asking how wives and husbands divide their housework as the time-use survey.

However, in surveys using the recall method, which include both the JPSC and the LOSEF, each spouse's report of the other spouse's share may differ from the self- 
reported housework share. ${ }^{4}$ In the LOSEF, husbands report that they perform $14.9 \%$ of the weekday housework, $5.7 \%$ higher than what their wives report for the husbands' share of the weekday housework. (Note that because the JPSC surveys only women, it lacks information about housework as reported by husbands.) Therefore, the recall method (which differs from the time-diary method, where respondents keep a record of the time spent on activities) may under- or overestimate the amount of housework performed by the respondents' spouses. ${ }^{5}$

\section{How is housework shared among married couples in Japan?}

We begin by presenting in Table 1 the average percentage share of housework performed by husbands and wives on weekdays and weekends based on the wives' employment status (nonworking, part-time work, and full-time work). ${ }^{6}$

Table 1 Summary statistics for selected variables by wives' employment status

\begin{tabular}{|c|c|c|c|c|c|c|}
\hline \multirow[b]{2}{*}{ Variables } & \multicolumn{2}{|c|}{ Wife not working } & \multicolumn{2}{|c|}{ Wife working part-time } & \multicolumn{2}{|c|}{ Wife working full-time } \\
\hline & Mean & SD & $\overline{\text { Mean }}$ & SD & $\overline{\text { Mean }}$ & SD \\
\hline \multicolumn{7}{|l|}{ Share of housework } \\
\hline Wife: weekday & 88.08 & 16.03 & 86.39 & 16.47 & 72.00 & 24.89 \\
\hline Wife: weekend & 75.79 & 19.85 & 76.93 & 19.19 & 67.78 & 22.39 \\
\hline Husband: weekday & 8.453 & 13.01 & 8.776 & 12.80 & 21.02 & 21.75 \\
\hline Husband: weekend & 20.45 & 18.06 & 18.30 & 17.52 & 27.16 & 21.64 \\
\hline Other family members: weekday & 3.464 & 9.520 & 4.818 & 11.22 & 6.840 & 16.84 \\
\hline Other family members: weekend & 3.758 & 9.628 & 4.767 & 10.12 & 5.011 & 12.31 \\
\hline Wife's age & 38.39 & 6.699 & 40.93 & 6.251 & 38.48 & 7.332 \\
\hline \multicolumn{7}{|l|}{ Wife's education } \\
\hline Less than high school & 0.024 & 0.152 & 0.019 & 0.138 & 0.015 & 0.122 \\
\hline High school & 0.305 & 0.461 & 0.364 & 0.481 & 0.281 & 0.450 \\
\hline Junior college & 0.365 & 0.481 & 0.406 & 0.491 & 0.351 & 0.477 \\
\hline College & 0.307 & 0.461 & 0.211 & 0.408 & 0.353 & 0.478 \\
\hline Wife's log of labor income & 0.000 & 0.000 & 4.298 & 0.965 & 5.476 & 0.836 \\
\hline Husband's age & 39.86 & 7.040 & 42.70 & 6.836 & 40.22 & 7.945 \\
\hline \multicolumn{7}{|l|}{ Husband's education } \\
\hline Less than high school & 0.025 & 0.156 & 0.042 & 0.202 & 0.039 & 0.194 \\
\hline High school & 0.246 & 0.431 & 0.351 & 0.477 & 0.273 & 0.446 \\
\hline Junior college & 0.128 & 0.334 & 0.170 & 0.376 & 0.177 & 0.382 \\
\hline College & 0.601 & 0.490 & 0.436 & 0.496 & 0.510 & 0.500 \\
\hline Husband not working & 0.012 & 0.109 & 0.011 & 0.102 & 0.025 & 0.157 \\
\hline Husband works $\geq 60$ h per week & 0.257 & 0.437 & 0.218 & 0.413 & 0.222 & 0.416 \\
\hline Husband's log of labor income & 6.191 & 0.844 & 6.128 & 0.858 & 5.867 & 1.179 \\
\hline Length of marriage & 11.32 & 6.946 & 15.02 & 6.489 & 11.73 & 8.208 \\
\hline \multicolumn{7}{|l|}{ Number of children } \\
\hline Preschool children & 0.690 & 0.814 & 0.296 & 0.591 & 0.315 & 0.602 \\
\hline Elementary school children & 0.444 & 0.695 & 0.542 & 0.741 & 0.312 & 0.612 \\
\hline Junior/high school children & 0.332 & 0.635 & 0.655 & 0.793 & 0.429 & 0.719 \\
\hline Children older than 19 & 0.123 & 0.388 & 0.250 & 0.527 & 0.212 & 0.505 \\
\hline$N$ & 2779 & & 2545 & & 2267 & \\
\hline
\end{tabular}


In Table 1, the weekday share of the housework is $88.1 \%$ for nonworking wives, which is the largest percentage of housework among the wives, whereas the husbands of these nonworking wives perform only $8.5 \%$ of the housework. Wives who work part-time perform $86.4 \%$ of the housework, and their husbands perform $8.8 \%$. Wives who work full-time perform $72.0 \%$ of the housework, while the figure for their husbands is $21.0 \%$. The weekday share of housework performed by wives who do not work and wives who work part-time is substantial. The weekday share of housework performed by husbands whose wives work full-time is more than twice as large as that of husbands whose wives work part-time or do not work at all, although it remains less than one-fourth the amount of housework that is performed by their wives.

In contrast, the weekend share of housework for nonworking wives is $75.8 \%$, whereas their husbands' share is $20.5 \%$. Wives who work part-time (full-time) perform $76.9 \%$ $(67.8 \%)$ of the weekend housework, and their husbands perform $18.3 \%$ (21.6\%). Although the husband's share of housework on weekends is significantly larger than on weekdays, the distribution of housework between wives and husbands on weekends remains unequal. ${ }^{7}$

Next, we estimate the relationship between personal and family characteristics and wives' and husbands' shares of housework on weekdays and weekends. The independent variables included in the regression include the following: length of marriage; wife's age, education, employment status, and labor income; husband's age, education, work status (not working and working more than $60 \mathrm{~h}$ per week), and labor income; and number of children in the household (preschool, elementary school, junior/senior high school, and children aged 19 and older). ${ }^{8}$ The estimation results are reported in Table 2: column 1 reports the wives' weekday share of housework as the dependent variable; column 2 reports the wives' weekend share of housework; column 3 reports the husbands' weekday share of housework; and column 4 reports the husbands' weekend share of housework.

For households in which husbands work 60 or more hours per week, the husbands' share of housework decreases by 3.453 percentage points on weekdays and by 3.996 percentage points on weekends, whereas their wives' share of housework increases by 3.776 percentage points on weekdays and by 4.216 percentage points on weekends. Not surprisingly, when husbands work long hours, their share of housework decreases, and the wives' share increases-on both weekdays and weekends.

When the husbands' labor income is greater by $10 \%$, their weekday share of housework decreases by 24.0 percentage points, and their wives' weekday share of housework increases by 37.4 percentage points. However, there are no significant changes in spouses' shares of weekend housework. Therefore, wives with higher-earning husbands perform a greater share of housework on weekdays but not on weekends. ${ }^{9}$

When the labor income of the wives is $10 \%$ greater, their share of housework decreases by 22.7 percentage points on weekdays and by 16.4 percentage points on weekends, and their husbands' share of housework increases by 17.0 percentage points on weekdays and by 14.6 percentage points on weekends. Wives' paid work can contribute to their empowerment at home on both weekdays and weekends, which is consistent with family bargaining models (Lundberg et al. 1997; Manser and Brown 1980). ${ }^{10}$ The patterns identified in this section are found in previous studies on housework. 
Table 2 OLS estimate of the shares of wife's and husband's housework on weekdays and weekends

\begin{tabular}{|c|c|c|c|c|c|c|c|c|c|c|c|c|}
\hline \multirow{3}{*}{$\frac{\text { Variables }}{\text { Wife's age }}$} & \multicolumn{3}{|c|}{$\begin{array}{l}\text { Wife's } \\
\text { weekday share } \\
\text { of housework }\end{array}$} & \multicolumn{3}{|c|}{$\begin{array}{l}\text { Wife's } \\
\text { weekend share } \\
\text { of housework }\end{array}$} & \multicolumn{3}{|c|}{$\begin{array}{l}\text { Husband's } \\
\text { weekday share } \\
\text { of housework }\end{array}$} & \multicolumn{3}{|c|}{$\begin{array}{l}\text { Husband's } \\
\text { weekend share } \\
\text { of housework }\end{array}$} \\
\hline & \multirow{2}{*}{$\begin{array}{c}\text { Coef. } \\
0.393\end{array}$} & \multicolumn{2}{|l|}{ SE } & \multirow{2}{*}{$\begin{array}{l}\text { Coef. } \\
0.387\end{array}$} & \multicolumn{2}{|l|}{ SE } & \multirow{2}{*}{$\begin{array}{l}\text { Coef. } \\
-0.317\end{array}$} & \multicolumn{2}{|l|}{ SE } & \multirow{2}{*}{$\begin{array}{l}\text { Coef. } \\
-0.315\end{array}$} & \multicolumn{2}{|l|}{ SE } \\
\hline & & 0.089 & $* * *$ & & 0.097 & $* * *$ & & 0.077 & $* * *$ & & 0.089 & $* * *$ \\
\hline \multicolumn{13}{|l|}{ Wife's education } \\
\hline Less than high school & -0.966 & 2.504 & & 0.559 & 2.454 & & 0.612 & 1.829 & & 0.058 & 2.109 & \\
\hline Junior college & 0.808 & 0.712 & & 0.830 & 0.758 & & -0.765 & 0.551 & & -0.736 & 0.675 & \\
\hline College & 0.180 & 0.821 & & -0.006 & 0.914 & & 0.626 & 0.680 & & 0.707 & 0.847 & \\
\hline Wife works part-time & 6.857 & 1.609 & $* * *$ & 5.254 & 1.610 & $* * *$ & -4.833 & 1.304 & $* * *$ & -4.436 & 1.483 & $* * *$ \\
\hline Wife works full-time & -3.029 & 2.036 & & 0.310 & 2.017 & & 3.033 & 1.654 & * & -0.244 & 1.833 & \\
\hline Wife's log of labor income & -2.274 & 0.356 & $* * *$ & -1.639 & 0.338 & $* * *$ & 1.703 & 0.290 & $* * *$ & 1.463 & 0.312 & $* * *$ \\
\hline Husband's age & -0.211 & 0.077 & $* * *$ & -0.016 & 0.077 & & 0.192 & 0.066 & $* * *$ & 0.036 & 0.071 & \\
\hline \multicolumn{13}{|l|}{ Husband's education } \\
\hline Less than high school & 0.838 & 1.887 & & 0.219 & 1.985 & & -1.248 & 1.419 & & -0.575 & 1.662 & \\
\hline Junior college & 1.641 & 0.882 & * & -0.579 & 0.942 & & -0.718 & 0.699 & & 1.594 & 0.849 & $*$ \\
\hline College & 0.656 & 0.746 & & -1.020 & 0.810 & & -0.253 & 0.593 & & 1.843 & 0.727 & ** \\
\hline Husband not working & 9.406 & 5.090 & * & -1.390 & 4.681 & & 0.236 & 4.689 & & 8.837 & 4.472 & $* *$ \\
\hline $\begin{array}{l}\text { Husband works more than } \\
60 \mathrm{~h} \text { per week }\end{array}$ & 3.776 & 0.579 & $* * *$ & 4.216 & 0.638 & $* * *$ & -3.453 & 0.461 & $* * *$ & -3.996 & 0.577 & $* * *$ \\
\hline Husband's log of labor income & 3.735 & 0.594 & $* * *$ & 0.729 & 0.544 & & -2.395 & 0.483 & $* * *$ & 0.339 & 0.491 & \\
\hline Length of marriage & 0.103 & 0.083 & & 0.111 & 0.089 & & -0.156 & 0.071 & $* *$ & -0.165 & 0.081 & $* *$ \\
\hline \multicolumn{13}{|l|}{ Number of children } \\
\hline reschool children & 0.168 & 0.398 & & -0.692 & 0.448 & & -0.957 & 0.331 & $* * *$ & 0.446 & 0.415 & \\
\hline Elementary school children & -0.784 & 0.402 & * & -0.401 & 0.430 & & -0.823 & 0.319 & $* * *$ & -1.114 & 0.386 & $* * *$ \\
\hline Junior/high school children & -0.832 & 0.445 & * & -0.270 & 0.482 & & -1.178 & 0.366 & $* * *$ & -1.612 & 0.436 & $* * *$ \\
\hline Children older than 19 & -0.632 & 0.706 & & -0.279 & 0.755 & & -1.139 & 0.593 & * & -1.225 & 0.688 & $*$ \\
\hline Respondent is wife & 5.747 & 0.581 & $* * *$ & 7.189 & 0.621 & $* * *$ & -6.030 & 0.478 & $* * *$ & -7.536 & 0.570 & $* * *$ \\
\hline$R^{2}$ & 0.190 & & & 0.110 & & & 0.216 & & & 0.152 & & \\
\hline$N$ & 6318 & & & 6300 & & & 6318 & & & 6300 & & \\
\hline
\end{tabular}

Note: All models include an indicator variable for whether the family has a mortgage, the amount of any monthly mortgage payment, whether the amount of the mortgage was not reported, whether the total family assets were not reported, the amount of total family assets, the respondents' place of residence, and the survey year. Robust standard errors clustered at the individual level are in parentheses

${ }^{*} p<0.05 ;{ }^{* *} p<0.01 ;{ }^{* * *} p<0.001$

\section{When are wives more satisfied with their husbands?}

We examine the relationship between the husbands' share of housework on both weekdays and weekends and wives' satisfaction with their husbands. Table 3 displays the means of the spouses' share of housework on weekdays and weekends based on satisfaction with their spouse. For wives who report higher satisfaction with their husbands, their husbands' average share of housework is higher, regardless of the employment status of the wife. When we compare "completely happy" wives and "completely unhappy" wives, the share of housework performed by the husbands of the former group is more than double than that performed by husbands in the latter group. For example, for wives working full-time, their husbands' weekday share of housework is $6.99 \%$ for "completely unhappy $=1$ " wives but $22.1 \%$ for "completely happy $=6$ " wives, 
Table 3 Average share of spouse's housework by satisfaction with the spouse and by wife's employment status

\begin{tabular}{|c|c|c|c|c|c|c|c|c|c|}
\hline \multirow{2}{*}{$\begin{array}{l}\text { Wife's satisfaction } \\
\text { with husband }\end{array}$} & \multicolumn{3}{|c|}{ Wife not working } & \multicolumn{3}{|c|}{ Wife working part-time } & \multicolumn{3}{|c|}{ Wife working full-time } \\
\hline & $\begin{array}{l}\text { Husband's } \\
\text { weekday } \\
\text { share of } \\
\text { housework }\end{array}$ & $\begin{array}{l}\text { Husband's } \\
\text { weekend } \\
\text { share of } \\
\text { housework }\end{array}$ & $N$ & $\begin{array}{l}\text { Husband's } \\
\text { weekday } \\
\text { share of } \\
\text { housework }\end{array}$ & $\begin{array}{l}\text { Husband's } \\
\text { weekend } \\
\text { share of } \\
\text { housework }\end{array}$ & N & $\begin{array}{l}\text { Husband's } \\
\text { weekday } \\
\text { share of } \\
\text { housework }\end{array}$ & $\begin{array}{l}\text { Husband's } \\
\text { weekend } \\
\text { share of } \\
\text { housework }\end{array}$ & $N$ \\
\hline $\begin{array}{l}1=\text { completely } \\
\text { unhappy }\end{array}$ & 2.59 & 4.84 & 32 & 4.29 & 8.66 & 70 & 6.99 & 8.72 & 69 \\
\hline 2 & 3.58 & 8.95 & 57 & 5.82 & 8.51 & 104 & 9.66 & 15.43 & 74 \\
\hline 3 & 4.29 & 10.62 & 161 & 5.46 & 12.26 & 235 & 12.79 & 18.53 & 169 \\
\hline 4 & 4.68 & 15.51 & 384 & 6.76 & 15.69 & 522 & 14.79 & 19.82 & 313 \\
\hline 5 & 6.24 & 18.80 & 387 & 7.99 & 16.22 & 413 & 19.54 & 24.37 & 294 \\
\hline $\begin{array}{l}6=\text { completely } \\
\text { happy }\end{array}$ & 7.69 & 23.93 & 202 & 10.28 & 21.49 & 201 & 22.14 & 30.81 & 216 \\
\hline \multirow{2}{*}{$\begin{array}{l}\text { Husband's } \\
\text { satisfaction } \\
\text { with wife }\end{array}$} & \multicolumn{3}{|c|}{ Wife not working } & \multicolumn{3}{|c|}{ Wife working part-time } & \multicolumn{3}{|c|}{ Wife working full-time } \\
\hline & $\begin{array}{l}\text { Wife's } \\
\text { weekday } \\
\text { share of } \\
\text { housework }\end{array}$ & $\begin{array}{l}\text { Wife's } \\
\text { weekend } \\
\text { share of } \\
\text { housework }\end{array}$ & $N$ & $\begin{array}{l}\text { Wife's } \\
\text { weekday } \\
\text { share of } \\
\text { housework }\end{array}$ & $\begin{array}{l}\text { Wife's } \\
\text { weekend } \\
\text { share of } \\
\text { housework }\end{array}$ & $N$ & $\begin{array}{l}\text { Wife's } \\
\text { weekday } \\
\text { share of } \\
\text { housework }\end{array}$ & $\begin{array}{l}\text { Wife's } \\
\text { weekend } \\
\text { share of } \\
\text { housework }\end{array}$ & N \\
\hline $\begin{array}{l}1=\text { completely } \\
\text { unhappy }\end{array}$ & 68.00 & 49.06 & 16 & 76.58 & 69.21 & 19 & 55.29 & 55.43 & 28 \\
\hline 2 & 85.66 & 77.94 & 50 & 84.67 & 68.33 & 48 & 66.67 & 62.78 & 45 \\
\hline 3 & 83.05 & 72.30 & 138 & 82.95 & 73.10 & 95 & 64.47 & 61.92 & 104 \\
\hline 4 & 87.12 & 74.55 & 362 & 85.36 & 73.85 & 266 & 67.77 & 63.11 & 293 \\
\hline 5 & 86.64 & 73.75 & 608 & 85.00 & 72.35 & 344 & 68.73 & 61.96 & 351 \\
\hline $\begin{array}{l}6=\text { completely } \\
\text { happy }\end{array}$ & 86.08 & 72.04 & 360 & 85.15 & 74.20 & 206 & 69.50 & 64.66 & 208 \\
\hline
\end{tabular}

Note: Satisfaction with spouse is rated on a 6-point scale: $1=$ "completely unhappy" and 6= "completely happy"

representing a threefold difference. Therefore, the extent of the husbands' participation in housework is positively related to their wives' satisfaction. In contrast, as the husbands' satisfaction with their wives increases, the average share of housework peaks around $85 \%$ on weekdays and around $73 \%$ on weekends for both wives who work part-time and wives who do not work. For full-time working wives, as their husbands' spousal satisfaction increases, the wives' average weekday and weekend share of housework peaks at around $65 \%$. Therefore, the wives' satisfaction with their husbands appears to be strongly related to the spouses' share of housework, but this relationship is not as strong for the husbands' satisfaction with their wives.

Next, we estimate the effect of the spouses' share of housework on weekdays and weekends on satisfaction with the spouse by utilizing the satisfaction model presented in Usui (2008). Let the utility individual $i$ receives from marriage at time $t$ be $U_{i t}$ and the rate of satisfaction with the spouse be $S_{i t}$. We approximate the utility as $S_{i t}=b U_{i t}$, where $b>0$. By substituting the equation of utility into the equation of satisfaction, we can estimate up to scale the preference parameters on the equation of utility. Because the rate of satisfaction with the spouse is indexed on a scale from one to six, we estimate the satisfaction model by ordered probit. The independent variables are the spouse's and other family members' share of housework on weekdays and weekends and the control variables used in Table 2. Table 4, column 1 presents the ordered probit estimates for the sample of nonworking wives; column 2, the sample of part-time 
Table 4 Ordered Probit Estimate of Satisfaction with Spouse

\begin{tabular}{|c|c|c|c|c|c|c|c|c|c|c|c|c|}
\hline \multirow[b]{4}{*}{ Independent Variables } & \multicolumn{9}{|c|}{ Wife's Satisfaction with Husband } & \multirow{2}{*}{\multicolumn{3}{|c|}{$\begin{array}{l}\text { Husband's } \\
\text { Satisfaction with } \\
\text { Wife }\end{array}$}} \\
\hline & \multicolumn{3}{|c|}{$\begin{array}{l}\text { Wife Not } \\
\text { Working }\end{array}$} & \multicolumn{3}{|c|}{$\begin{array}{l}\text { Wife Working } \\
\text { Part-time }\end{array}$} & \multicolumn{3}{|c|}{$\begin{array}{l}\text { Wife Working } \\
\text { Full-time }\end{array}$} & & & \\
\hline & \multicolumn{3}{|l|}{ (1) } & \multicolumn{3}{|l|}{$(2)$} & \multicolumn{3}{|l|}{ (3) } & \multicolumn{3}{|l|}{ (4) } \\
\hline & $\overline{\text { Coef. }}$ & SE & & $\overline{\text { Coef. }}$ & SE & & $\overline{\text { Coef. }}$ & SE & & $\overline{\text { Coef. }}$ & SE & \\
\hline \multicolumn{13}{|l|}{ Share of Housework } \\
\hline Spouse: Weekday & -0.009 & 0.005 & * & 0.007 & 0.004 & * & 0.009 & 0.003 & $* * *$ & 0.003 & 0.002 & * \\
\hline Spouse: Weekend & 0.020 & 0.003 & $* * *$ & 0.011 & 0.003 & $* * *$ & 0.007 & 0.003 & $* *$ & 0.001 & 0.001 & \\
\hline $\begin{array}{l}\text { Other Family Members: } \\
\text { Weekday }\end{array}$ & 0.011 & 0.006 & * & -0.00002 & 0.004 & & -0.002 & 0.004 & & -0.009 & 0.004 & $* *$ \\
\hline $\begin{array}{l}\text { Other Family Members: } \\
\text { Weekend }\end{array}$ & -0.015 & 0.006 & $* * *$ & 0.002 & 0.006 & & 0.003 & 0.005 & & 0.011 & 0.004 & $* *$ \\
\hline Age & -0.023 & 0.013 & * & -0.028 & 0.013 & $* *$ & -0.002 & 0.015 & & -0.007 & 0.008 & \\
\hline \multicolumn{13}{|l|}{ Education } \\
\hline Less than High School & -0.515 & 0.234 & $* *$ & 0.492 & 0.305 & & -0.763 & 0.472 & & -0.092 & 0.147 & \\
\hline Junior College & -0.015 & 0.095 & & 0.084 & 0.085 & & 0.080 & 0.111 & & 0.043 & 0.080 & \\
\hline College & -0.092 & 0.113 & & 0.063 & 0.112 & & 0.029 & 0.145 & & -0.044 & 0.065 & \\
\hline Log of Labor Income & - & - & & -0.005 & 0.030 & & 0.074 & 0.041 & * & 0.028 & 0.030 & \\
\hline Spouse Age & -0.011 & 0.010 & & -0.012 & 0.010 & & -0.021 & 0.010 & $* *$ & -0.008 & 0.007 & \\
\hline \multicolumn{13}{|l|}{ Spouse Education } \\
\hline Less than High School & 0.031 & 0.245 & & 0.014 & 0.182 & & 0.319 & 0.217 & & -0.265 & 0.177 & \\
\hline Junior College & 0.213 & 0.121 & * & 0.114 & 0.107 & & -0.124 & 0.138 & & 0.003 & 0.060 & \\
\hline College & 0.087 & 0.096 & & 0.132 & 0.091 & & 0.197 & 0.117 & * & 0.171 & 0.070 & $* *$ \\
\hline Spouse Not Working & 1.285 & 0.524 & $* *$ & 0.818 & 0.518 & & 0.324 & 0.486 & & 0.142 & 0.165 & \\
\hline $\begin{array}{l}\text { Spouse Works More than } 60 \mathrm{~h} \\
\text { per Week }\end{array}$ & -0.085 & 0.078 & & 0.151 & 0.083 & * & 0.112 & 0.094 & & 0.351 & 0.212 & $*$ \\
\hline Spouse Log of Labor Income & 0.112 & 0.071 & & 0.193 & 0.074 & $* * *$ & 0.158 & 0.069 & $* *$ & 0.007 & 0.033 & \\
\hline Length of Marriage & 0.010 & 0.012 & & 0.011 & 0.012 & & -0.003 & 0.013 & & -0.014 & 0.006 & ** \\
\hline \multicolumn{13}{|l|}{ Number of Children } \\
\hline Preschool Children & -0.223 & 0.052 & $* * *$ & -0.224 & 0.066 & $* * *$ & -0.205 & 0.069 & $* * *$ & -0.146 & 0.037 & $* * *$ \\
\hline Elementary School Children & -0.072 & 0.053 & & -0.068 & 0.054 & & -0.239 & 0.073 & $* * *$ & -0.068 & 0.036 & $*$ \\
\hline Junior/High School Children & -0.192 & 0.067 & $* * *$ & -0.117 & 0.056 & $* *$ & -0.254 & 0.066 & $* * *$ & -0.149 & 0.040 & *** \\
\hline Children Older than 19 & -0.100 & 0.103 & & -0.042 & 0.088 & & -0.071 & 0.092 & & 0.055 & 0.056 & \\
\hline Log pseudolikelihood & \multicolumn{3}{|l|}{-1526.6} & \multicolumn{3}{|l|}{-1841.7} & \multicolumn{3}{|l|}{-1353.0} & \multicolumn{3}{|c|}{-4484.3} \\
\hline $\mathrm{N}$ & \multicolumn{3}{|l|}{1060} & \multicolumn{3}{|l|}{1207} & \multicolumn{3}{|l|}{897} & \multicolumn{3}{|l|}{3104} \\
\hline
\end{tabular}

Note: See note in Table 2 for other variables included in the regression. Robust standard errors clustered at the individual level are in parentheses.

${ }^{*} \mathrm{p}<0.05,{ }^{* *} \mathrm{p}<0.01,{ }^{* * *} \mathrm{p}<0.001$.

working wives; column 3, the sample of full-time working wives; and column 4, the sample of husbands. We also estimate the average marginal probability effects of the spousal share of housework on weekdays and weekends on satisfaction with the spouse in Table 5 for the corresponding samples in columns 1 to 4 .

The weekday share of housework of husbands whose wives work part- and full-time is positively related to the wives' satisfaction with their husbands (Table 4, columns 2 and 3). Similarly, the wives' weekday share of housework is positively related to the husbands' satisfaction with their wives (Table 4, column 4). Therefore, the more housework their 
Table 5 Marginal Probability Effects of Spousal Share of Housework on Satisfaction with Spouse (Marginal effects at the mean)

\begin{tabular}{|c|c|c|c|c|c|c|c|c|c|c|c|c|c|c|c|c|c|}
\hline \multirow{3}{*}{$\begin{array}{l}\text { Wife's Satisfaction with } \\
\text { Husband }\end{array}$} & \multicolumn{4}{|c|}{ Wife Not Working } & \multicolumn{4}{|c|}{ Wife Working Part-time } & \multicolumn{4}{|c|}{ Wife Working Full-time } & \multirow{3}{*}{ Husband's Satisfaction with Wife } & \multirow{2}{*}{\multicolumn{2}{|c|}{$\begin{array}{l}\text { Husband } \\
\text { Wife's } \\
\text { Weekday } \\
\text { Share of } \\
\text { Housework }\end{array}$}} & \multirow{2}{*}{\multicolumn{2}{|c|}{$\begin{array}{l}\text { Husband } \\
\text { Wife's } \\
\text { Weekend } \\
\text { Share of } \\
\text { Housework }\end{array}$}} \\
\hline & \multicolumn{2}{|c|}{$\begin{array}{l}\text { Husband's } \\
\text { Weekday Share } \\
\text { of Housework }\end{array}$} & \multicolumn{2}{|c|}{$\begin{array}{l}\text { Husband's } \\
\text { Weekend Share } \\
\text { of Housework }\end{array}$} & \multicolumn{2}{|c|}{$\begin{array}{l}\text { Husband's } \\
\text { Weekday Share } \\
\text { of Housework }\end{array}$} & \multicolumn{2}{|c|}{$\begin{array}{l}\text { Husband's } \\
\text { Weekend Share } \\
\text { of Housework }\end{array}$} & \multicolumn{2}{|c|}{$\begin{array}{l}\text { Husband's } \\
\text { Weekday Share } \\
\text { of Housework }\end{array}$} & \multicolumn{2}{|c|}{$\begin{array}{l}\text { Husband's } \\
\text { Weekend Share } \\
\text { of Housework }\end{array}$} & & & & & \\
\hline & $d y / d x$ & SE & $d y / d x$ & SE & $d y / d x$ & SE & $d y / d x$ & SE & $d y / d x$ & SE & $d y / d x$ & SE & & $d y / d x$ & SE & $d y / d x$ & SE \\
\hline 1 = completely unhappy & 0.039 & $0.022 *$ & -0.086 & $0.020 * * *$ & -0.054 & 0.033 & -0.084 & $0.024^{* * *}$ & -0.075 & $0.024^{* * *}$ & -0.059 & $0.024 * * *$ & $1=$ completely unhappy & -0.010 & $0.006 *$ & -0.003 & 0.005 \\
\hline 2 & 0.060 & $0.033 *$ & -0.133 & $0.027 * * *$ & -0.062 & $0.037 *$ & -0.097 & $0.030^{* * *}$ & -0.077 & $0.026 * * *$ & -0.061 & $0.024 * * *$ & 2 & -0.021 & $0.011 *$ & -0.007 & 0.010 \\
\hline 3 & 0.145 & $0.076 *$ & -0.320 & $0.050 * * *$ & -0.105 & $0.063 *$ & -0.163 & $0.046 * * *$ & -0.132 & $0.041 * * *$ & -0.104 & $0.042 * * *$ & 3 & -0.037 & $0.021 *$ & -0.012 & 0.018 \\
\hline 4 & 0.126 & $0.066 *$ & -0.278 & $0.044^{* * *}$ & -0.053 & 0.033 & -0.082 & $0.026^{* * *}$ & -0.081 & $0.026 * * *$ & -0.064 & $0.028 * * *$ & 4 & -0.047 & $0.025 *$ & -0.015 & 0.022 \\
\hline 5 & -0.161 & $0.085 *$ & 0.355 & $0.057 * * *$ & 0.132 & 0.079 * & 0.207 & $0.058 * * *$ & 0.149 & $0.046 * * *$ & 0.117 & $0.048^{* * *}$ & 5 & 0.031 & $0.017 *$ & 0.010 & 0.015 \\
\hline $6=$ completely happy & -0.209 & $0.110 *$ & 0.462 & $0.065 * * *$ & 0.141 & $0.084 *$ & 0.220 & $0.061 * * *$ & 0.217 & $0.064 * * *$ & 0.170 & $0.068 * * *$ & $6=$ completely happy & 0.085 & $0.046 *$ & 0.028 & 0.040 \\
\hline
\end{tabular}

Note: Table 5 reports average marginal probability effects of spousal share of housework (from 0 to 100 percent) on satisfaction with spouse. See note in Table 2 for other variables included in the regression. Robust standard errors clustered at the individual level are in parentheses.

${ }^{*} p<0.05,{ }^{* *} p<0.01,{ }^{* * *} p<0.001$. 
spouse performs on weekdays, the greater the spousal satisfaction experienced by both husbands and working wives. In particular, given an increase in the husband's weekday share of housework from 0 to $100 \%$, the probability of being "completely happy $=6$ " increases by $14.1 \%$ (21.7 \%) for part-time (full-time) working wives, while the probability of being "completely unhappy =1" decreases by $5.4 \%$ (7.5 \%) for part-time (full-time) working wives (Table 5). In the meantime, given an increase in the wife's weekday share of housework from 0 to $100 \%$, the probability of the husband being "completely happy $=6$ " increases by $8.5 \%$, while the probability of the husband being "completely unhappy $=1$ " decreases by $1.0 \%$. Therefore, the marginal probability effects of the spousal weekday share of housework on satisfaction with the spouse are greater for the wives' satisfaction than for the husbands' satisfaction. In dual-earner families, wives are more satisfied with the spouse than are their husbands when the spouse does a larger share of the housework.

By contrast, the weekday share of housework of the husbands of nonworking wives is negatively related to the wives' satisfaction with their husbands (Table 4, column 1). Specifically, the increase in the husband's weekday share of housework from 0 to $100 \%$ is associated with the wife being $20.9 \%$ less likely to be "completely happy $=6$ " and $3.9 \%$ more likely to be "completely unhappy =1" (Table 5). Therefore, working wives are more satisfied with their husbands when the husband performs a larger share of the housework on weekdays, but the opposite is the case for nonworking wives.

Regardless of the wives' employment status, the husbands' weekend share of housework is positively related to the wives' satisfaction with their husbands (Table 4, columns 1, 2, and 3). In particular, given an increase in the husband's weekend share of housework from 0 to $100 \%$, the probability of being "completely happy $=6$ " increases by 46.2, 22.2, and $17.0 \%$ for wives who do not work, work part-time, and work full-time, respectively, while the probability of being "completely unhappy $=1$ " decreases by 8.6, 8.4, and $5.9 \%$ for wives who do not work, work part-time, and work full-time, respectively. However, no significant relationship appears between the wives' weekend share of housework and the husbands' satisfaction with their wives (Table 4, column 4). In particular, for husbands, given an increase in the wife's weekend share of housework from 0 to $100 \%$, the probability of being "completely happy $=6$ " increases by only $2.8 \%$, which is statistically insignificant, and the probability of being "completely unhappy $=1$ " decreases by only $0.3 \%$, which is also statistically insignificant. Therefore, wives are more satisfied if the spouse increases the share of housework on weekends than are their husbands.

The issue of how to divide housework can naturally become more contentious for couples who have small children, as such couples must spend more time on housework (including childcare). To address this issue, we estimate the satisfaction model separately for those who have preschool children and those who do not. For full-time working wives, their husbands' weekday share of housework is statistically significant and positively related to the wives' satisfaction with their husbands for families with preschool children but statistically insignificant and positively related for families without preschool children. By contrast, for nonworking wives, their husbands' weekday share of housework is statistically significant and negatively related to the wives' satisfaction with their husbands for families without preschool children, but statistically insignificant and negatively related for families with preschool children. These results indicate that the presence or absence of small children exerts heterogeneous effects on the relationship between the division of housework and spousal satisfaction. 
Finally, we estimate a first-difference model that includes indicator variables for changes in the wives' employment status between 2012 and 2014. The results are displayed in Table $6 .{ }^{11}$ In families in which the wives transition from part-time work in 2012 to full-time work in 2014, both the wives and husbands report that they are more satisfied with their spouse if that spouse increases their weekday share of housework. However, relying on themselves (i.e., the husband or wife alone) to perform housework on weekdays may not be feasible for dual-earner families, because nearly $22 \%$ of Japanese husbands work more than $60 \mathrm{~h}$ per week and are thus unable to perform more housework on weekdays.

\section{Conclusions}

Using the LOSEF, which was administered in 2012 and 2014, we find that a large share of housework in Japanese homes is performed by wives, and we find that the difference between the spouses' shares of housework is the largest for nonworking and part-time working wives. In addition, we find that husbands tend to perform a greater share of housework on weekends but that they nevertheless perform much less housework overall than their wives. These findings are consistent with previous studies on housework in the US, Australia, and the European countries, which have found that wives in those countries tend to take on a much greater proportion of the housework than their husbands (Craig and Mullan 2010; Manke et al. 1994).

Furthermore, we find that working wives' satisfaction with their husbands is higher when husbands perform a larger share of housework on weekdays. Husbands' satisfaction with their wives is also higher when their wives perform a larger share of the housework on weekdays, although the increase in satisfaction is lower than that of wives. Therefore, for dual-earner families, the spousal satisfaction of both husbands and wives increases as the share of housework performed on weekdays by the other spouse increases.

The dual-earner family structure is especially challenging in Japan because (i) household chores are rarely outsourced in Japan as previously noted and (ii) husbands are often unable to offer much help with household chores on weekdays due to their long work hours. This situation is likely to be one reason why the proportion of married women working full-time has not increased in Japan since the 1980s, remaining at approximately $30 \%$ (Abe 2011) ${ }^{12}$ However, the continuing decline in the Japanese population (due to the low birthrate and aging population) will inevitably prompt a shortage of workers and hamper economic growth unless more Japanese women work in the market. We therefore conclude that for dual-earner couples, (1) allowing husbands to flexibly choose their working hours and/or (2) providing affordable outside help to families may increase the number of married women willing and able to be part of the labor force. In an effort to promote the former, the Japanese government submitted a legislation to the Diet in 2015 to restrain employers from making their employees work long hours, including policies such as (1) increasing overtime pay for over $60 \mathrm{~h}$ worked a month to 1.5 times more than the regular rate of pay compared with the current 1.25 times, which applies equally to small- and medium-sized companies, (2) providing further advice and guidance to protect the health conditions of workers whose working hours are excessively long, (3) requesting companies to build consensus with labor unions to implement policies to remedy long working hours, and (4) allowing workers to spread out their working hours at will over a longer 
Table 6 Ordered probit estimates for changes in satisfaction with spouse

\begin{tabular}{|c|c|c|c|c|c|c|c|c|}
\hline \multirow[b]{2}{*}{ Variables } & \multicolumn{4}{|c|}{ Wife's satisfaction with husband } & \multicolumn{4}{|c|}{ Husband's satisfaction with wife } \\
\hline & Coef. & SE & Coef. & SE & Coef. & SE & Coef. & SE \\
\hline Spouse weekday share of housework $\times$ & -0.0002 & 0.003 & & & 0.005 & $0.002^{*}$ & & \\
\hline Wife: not working $\rightarrow$ not working & & & 0.012 & 0.009 & & & 0.001 & 0.005 \\
\hline Wife: part-time $\rightarrow$ part-time & & & 0.006 & 0.008 & & & 0.008 & 0.006 \\
\hline Wife: full-time $\rightarrow$ full-time & & & -0.004 & 0.006 & & & 0.001 & 0.004 \\
\hline Wife: not working $\rightarrow$ part-time & & & -0.018 & $0.010^{*}$ & & & 0.006 & 0.009 \\
\hline Wife: not working $\rightarrow$ full-time & & & -0.012 & 0.018 & & & 0.010 & 0.016 \\
\hline Wife: part-time $\rightarrow$ not working & & & -0.049 & $0.012^{* * *}$ & & & -0.002 & 0.011 \\
\hline Wife: part-time $\rightarrow$ full-time & & & 0.025 & $0.009^{* * *}$ & & & 0.016 & $0.010^{*}$ \\
\hline Wife: full-time $\rightarrow$ not working & & & 0.007 & 0.015 & & & 0.024 & $0.006^{* * *}$ \\
\hline Wife: full-time $\rightarrow$ part-time & & & -0.013 & 0.014 & & & -0.006 & 0.009 \\
\hline Spouse weekend share of housework $\times$ & 0.003 & 0.002 & & & 0.002 & 0.002 & & \\
\hline Wife: not working $\rightarrow$ not working & & & 0.001 & 0.004 & & & 0.007 & $0.004^{*}$ \\
\hline Wife: part-time $\rightarrow$ part-time & & & 0.003 & 0.005 & & & -0.008 & 0.006 \\
\hline Wife: full-time $\rightarrow$ full-time & & & 0.000 & 0.005 & & & -0.001 & 0.004 \\
\hline Wife: not working $\rightarrow$ part-time & & & 0.001 & 0.005 & & & -0.003 & 0.005 \\
\hline Wife: not working $\rightarrow$ full-time & & & 0.017 & 0.018 & & & 0.018 & $0.010^{*}$ \\
\hline Wife: part-time $\rightarrow$ not working & & & 0.034 & $0.009^{* * *}$ & & & 0.000 & 0.011 \\
\hline Wife: part-time $\rightarrow$ full-time & & & -0.012 & 0.008 & & & -0.001 & 0.007 \\
\hline Wife: full-time $\rightarrow$ not working & & & -0.001 & 0.011 & & & 0.008 & 0.005 \\
\hline Wife: full-time $\rightarrow$ part-time & & & 0.018 & 0.015 & & & 0.017 & $0.009^{* *}$ \\
\hline Wife: part-time $\rightarrow$ part-time & & & 0.019 & 0.083 & & & 0.030 & 0.086 \\
\hline Wife: full-time $\rightarrow$ full-time & & & 0.044 & 0.089 & & & 0.033 & 0.082 \\
\hline Wife: not working $\rightarrow$ part-time & & & -0.217 & 0.157 & & & -0.449 & $0.210^{* *}$ \\
\hline Wife: not working $\rightarrow$ full-time & & & -0.103 & 0.284 & & & -0.702 & $0.314^{* *}$ \\
\hline Wife: part-time $\rightarrow$ not working & & & -0.004 & 0.226 & & & 0.392 & 0.276 \\
\hline Wife: part-time $\rightarrow$ full-time & & & 0.098 & 0.128 & & & 0.022 & 0.175 \\
\hline Wife: full-time $\rightarrow$ not working & & & -0.267 & 0.366 & & & 0.013 & 0.309 \\
\hline Wife: full-time $\rightarrow$ part-time & & & 0.024 & 0.280 & & & 0.196 & 0.174 \\
\hline Wife's log of labor income & -0.034 & $0.017^{* *}$ & -0.010 & 0.033 & -0.023 & 0.015 & 0.076 & 0.047 \\
\hline Husband not working & 0.853 & $0.338^{* *}$ & 0.968 & $0.346^{* * *}$ & 0.371 & 0.411 & 0.555 & 0.422 \\
\hline $\begin{array}{l}\text { Husband works more than } \\
60 \mathrm{~h} \text { per week }\end{array}$ & -0.067 & 0.063 & -0.056 & 0.064 & -0.002 & 0.072 & 0.001 & 0.075 \\
\hline Husband's log of labor income & 0.180 & $0.046^{* * *}$ & 0.189 & $0.048^{* * *}$ & 0.092 & 0.054 & $0.098^{*}$ & $0.055^{*}$ \\
\hline $\begin{array}{l}\text { Other family members' share } \\
\text { on weekday }\end{array}$ & -0.001 & 0.004 & -0.001 & 0.004 & 0.001 & 0.005 & -0.001 & 0.005 \\
\hline $\begin{array}{l}\text { Other family members' share } \\
\text { on weekend }\end{array}$ & -0.002 & 0.004 & -0.004 & 0.004 & 0.009 & 0.005 & 0.009 & 0.006 \\
\hline \multicolumn{9}{|l|}{ Number of children } \\
\hline Preschool children & -0.195 & $0.072^{* * *}$ & -0.218 & $0.075^{* * *}$ & -0.161 & $0.061^{* * *}$ & -0.158 & $0.064^{* *}$ \\
\hline Elementary school children & -0.135 & $0.074^{*}$ & -0.150 & $0.079^{*}$ & -0.057 & 0.063 & -0.056 & 0.066 \\
\hline Junior/high school children & -0.140 & $0.070^{* *}$ & -0.136 & $0.074^{*}$ & -0.073 & 0.062 & -0.045 & 0.066 \\
\hline Children older than 19 & -0.051 & 0.079 & -0.058 & 0.081 & 0.034 & 0.085 & -0.006 & 0.088 \\
\hline \multirow[t]{2}{*}{ Log pseudolikelihood } & \multicolumn{2}{|l|}{-1855.1} & \multicolumn{2}{|l|}{-1804.8} & \multicolumn{2}{|l|}{-1952.6} & \multicolumn{2}{|l|}{-1864.8} \\
\hline & \multicolumn{2}{|l|}{1348} & \multicolumn{2}{|l|}{1319} & \multicolumn{2}{|l|}{1396} & \multicolumn{2}{|l|}{1344} \\
\hline
\end{tabular}

Note: All models include changes to the following variables between 2012 and 2014: whether the family had a mortgage, the amount of any monthly mortgage payment, whether the amount of the mortgage was not reported, whether the total family assets were not reported, the amount of total family assets, and respondents' place of residence. Robust standard errors clustered at the individual level are in parentheses

${ }^{*} p<0.05 ;{ }^{* *} p<0.01$; ${ }^{* * *} p<0.001$ 
period of time (from 1 to 3 months), enabling them to choose working hours more flexibly. If this new legislation is enacted, it may bring about actual changes such as more flexible working practices in Japan.

\section{Endnotes}

${ }^{1}$ Friedberg and Webb (2005) also apply the concept that the opportunity cost of leisure time (i.e., the substitution effect of wages) is smaller on weekends than it is on weekdays.

${ }^{2}$ Note that there may be cultural norms that restrict husbands from performing housework regardless of the comparative advantage relative to their wives. Based on this view, Kawaguchi and Lee (2015) provide an explanation as to why economically successful women tend to remain unmarried in East Asian countries. They show that recent "marriage immigration" (i.e., the immigration of women from less developed countries in order to marry men in more developed countries) is accounted for by (i) advancements in women's socioeconomic status in developed countries and (ii) insufficient adjustment to the cultural norms affecting the division of labor within a marriage, resulting in more women deciding to remain unmarried to avoid the additional burdens that marriage would entail.

${ }^{3}$ We check the validity of the marital satisfaction variable by examining whether the marital satisfaction in 2012 differed between those who remained married and those who were divorced or separated between 2012 and 2014. Of the 3556 individuals who were married in 2012, 42 were divorced between 2012 and 2014 and 12 were separated during the same period. Although few people had changed marital status, the average degree of spousal satisfaction in 2012 for those who continued to be married was 4.459, 3.256 for those who were divorced, and 3.000 for those who were separated. Therefore, spousal satisfaction was lower for those who were divorced or separated between 2012 and 2014, implying that the marital satisfaction variable is a reliable measure of happiness with the spouse.

${ }^{4}$ Stratton (2012) finds that the more husbands report disliking housework (cleaning, laundry, ironing, and food shopping), the less time they report spending on housework and the more time their wives report spending on housework.

${ }^{5}$ According to Ueda (2005), the Japanese Survey on Time Use and Leisure Activities (STU) - a time-diary survey-on average, a Japanese husband performs $11.2 \mathrm{~min}$ of housework per weekday, while a Japanese wife performs an average of $324.5 \mathrm{~min}$ of housework per weekday; thus, the data indicate that the husband's share of the housework on weekdays is $3.5 \%$, less than the percentages obtained by recall methods, such as the JPSC and the LOSEF. However, a time-diary survey, such as the STU, has two inherent disadvantages: (1) short-duration activities (less than $15 \mathrm{~min}$ ) are not recorded, and (2) secondary activities (i.e., those performed when a person is engaged in more than one activity at a time) are not recorded (Ueda 2005). The former disadvantage in particular could be a problem in capturing the amount of housework performed by husbands because many Japanese husbands may never, or rarely, perform 15 continuous minutes of housework.

${ }^{6}$ Full-time refers to 35 or more hours of work per week, whereas part-time refers to fewer than $35 \mathrm{~h}$ of work per week.

${ }^{7}$ This result is consistent with Foster and Kreisler (2012) in the US and Stancanelli and Stratton (2014) in the UK and France. Hook and Wolfe (2012) also find that 
husbands in the US, Germany, Norway, and the UK performed a greater share of childcare (one particular category of housework) on weekends than on weekdays.

${ }^{8}$ Other variables include an indicator for whether the family has a mortgage, the amount of any monthly mortgage payment, total family assets, place of residence, and the survey year (these estimates are not reported in Table 2).

${ }^{9}$ This result is similar to that of Yeung et al. (2001), who utilize the U.S. Panel Study of Income Dynamics and find that husbands' earnings have a negative relationship with the time they spent with children on weekdays but not on weekends.

${ }^{10}$ Spouses' decisions on the allocation of housework have also been studied by Bloemen and Stancanelli (2014), Kimmel and Connelly (2007), Connelly and Kimmel (2009), Ueda (2005), Bloemen et al. (2010), and Bredtmann (2014).

${ }^{11}$ When the number of preschool children increases, both husbands and wives report that they are less satisfied with their spouse, presumably due to the burden of childrearing. When the husband's labor income increases, both husbands and wives report that they are more satisfied with their spouse. This result is consistent with Lee and Ono (2008), who find that Japanese wives report higher marital happiness if they have higher household incomes.

${ }^{12}$ Using data from Australia, Germany, the US, and Korea, Hamermesh and Lee (2007) find that for the same amount of time spent in market work and household work, adults in households with higher earnings perceive more time stress (i.e., an absence of sufficient time to accomplish all their tasks) than those in households with lower earnings. To the extent that Japanese married couples are aware of this phenomenon, this could be an additional factor that is suppressing women's participation in the workforce.

\section{Acknowledgements}

For their helpful comments and suggestions, the authors would like to thank two anonymous referees, as well as Yoshinori Ito, Juan F. Jimeno, Daiji Kawaguchi, Soohyung Lee, David Neumark, Núria Rodríguez-Planas, Nobuyoshi Yamori, and the participants at the IZA/RIETI Workshop: Changing Demographics and the Labor Market. This paper is funded by a Grant-in-Aid for Scientific Research (Grant Numbers 22000001, 26285056, 26245039, and 15H05692) from Japan's Ministry of Education, Culture, Sports, Science and Technology.

Responsible editor: Daiji Kawaguchi

\section{Competing interests}

The IZA Journal of Labor Policy is committed to the IZA Guiding Principles of Research Integrity. The authors declare that they have observed these principles.

\section{Author details}

1JA Bank Aichi, Nagoya 464-8601, Japan. ${ }^{2}$ School of Economics, Saga University, Saga 657-8501, Japan. ${ }^{3}$ Graduate School of International Social Sciences, Yokohama National University, Yokohama 240-8501, Japan. ${ }^{4}$ Institute of Economic Research, Hitotsubashi University and IZA, Tokyo 186-8603, Japan.

Received: 30 July 2015 Accepted: 14 September 2016

Published online: 13 October 2016

References

Abe Y (2011) The equal employment opportunity law and labor force behavior of women in Japan. J Jpn Int Econ 25(1):39-55. doi:10.1016/j.jjie.2010.06.003

Aoki R (2012) A demographic perspective on Japan's "Lost Decades". Popul Dev Rev 38(supplement):103-112. doi:10. $1111 / j .1728-4457.2013 .00554 . x$

Bloemen HG, Stancanelli EGF (2014) Market hours, household work, child care, and wage rates of partners: an empirical analysis. Rev Econ Househ 12(1):51-81. doi: 10.1007/s11150-013-9219-4

Bloemen HG, Pasqua S, Stancanelli EGF (2010) An empirical analysis of the time allocation of Italian couples: are they responsive? Rev Econ Househ 8(3):345-369. doi:10.1007/s11150-009-9083-4

Bredtmann J (2014) The intra-household division of labor: an empirical analysis of spousal influences on individual time allocation. Labour: Review of Labour Economics and Industrial Relations 28(1):1-39. doi:10.1111/labr.12024

Cabinet Office, Government of Japan (2001) White paper on gender equality 2001 [in Japanese]., http://www.gender. 423 Q6go.jp/english_contents/about_danjo/whitepaper/pdf/ewp2001.pdf. 
Connelly R, Kimmel J (2009) Spousal influences on parents' non-market time choices. Rev Econ Househ 7(4):361-394. doi:10.1007/s11150-009-9060-y

Cortes P, Pan J (2013) Outsourcing household production: foreign domestic workers and native labor supply in Hong Kong. J Labor Econ 31(2):327-371. doi:10.1086/668675

Cortes P, Tasseda J (2011) Low-skilled immigration and the labor supply of highly skilled women. Am Econ J Appl Econ 3(3):88-123. doi:10.1257/app.3.3.88

Craig L, Mullan K (2010) Parenthood, gender and work-family time in the United States, Australia, Italy, France, and Denmark. J Marriage Fam 72(5):1344-1361. doi:10.1111/j.1741-3737.2010.00769.x

Davis SN, Greenstein TN (2004) Cross-national variations in the division of household labor. J Marriage Fam 66(5):12601271. doi:10.1111/j.0022-2445.2004.00091.x

Foster AC, Kreisler CJ (2012) Wife's employment and allocation of resources in families with children. Mon Labor Rev 135:3-13, http://www.bls.gov/opub/mlr/2012/09/art1full.pdf

Friedberg L, Webb A (2005) The chore wars: Household bargaining and leisure time. Departmant of Economics, University of Virginia, mimeo.

Goldin C, Katz LF (2008) Transitions: career and family life cycles of the educational elite. Am Econ Rev 98(2):363-369. doi:10.1257/aer.98.2.363

Greenstein TN (2009) National context, family satisfaction, and fairness in the division of household labor. J Marriage Fam 71(4):1039-1051. doi:10.1111/j.1741-3737.2009.00651.x

Hamermesh DS, Lee J (2007) Stressed out on four continents: time crunch or yuppie kvetch? Rev Econ Stat 89(2):374383. doi:10.1162/rest.89.2.374

Hook JL, Wolfe CM (2012) New fathers? Residential fathers' time with children in four countries. J Fam Issues 33(4):415450. doi:10.1177/0192513X11425779

Japan Institute for Labour Policy and Training (2014) A follow-up survey on families with children (first survey, 2013). Japan Institute for Labour Policy and Training Report, 115 [in Japanese]. http://www.jil.go.jp/institute/research/2014/115.htm. Accessed 24 Sept 2016

Kamo Y (1994) Division of household work in the United States and Japan. J Fam Issues 15(3):348-378. doi:10.1177/ 019251394015003002

Kawaguchi D, Lee S (2015) Brides for sale: Cross-border marriage and female immigration. Department of Economics, University of Maryland, mimeo.

Kimmel J, Connelly R (2007) Mothers' time choices: caregiving, leisure, home production, and paid work. J Hum Resour 42(3):643-681. doi:10.3368/jhr.XLII.3.643

Lee KS, Ono H (2008) Specialization and happiness in marriage: A U.S.-Japan comparison. Soc Sci Res 37(4):1216-1234. doi:10.1016/j.ssresearch.2005.02.001

Lundberg SJ, Pollak RA, Wales TJ (1997) Do husbands and wives pool their resources? Evidence from the United Kingdom child benefit. J Hum Resour 32(3):463-480. doi:10.2307/146179

Manke B, Seery BL, Crouter AC, McHale SM (1994) The three corners of domestic labor: mothers', fathers', and children's weekday and weekend housework. J Marriage Fam 56(3):657-668. doi:10.2307/352876

Manser M, Brown M (1980) Marriage and household decisionmaking: a bargaining analysis. Int Econ Rev 21(1):31-34. doi:10.2307/2526238

National Institute of Population and Social Security Research. 2012. Population Projections for Japan: 2011-2060 (With Long-Range Population Projections: 2061-2110) (in Japanese). Tokyo: National Institute of Population and Social Security Research.

Stancanelli EGF, Stratton LS (2014) Maids, appliances and couples' housework: the demand for inputs to domestic production. Economica 81(323):445-467. doi:10.1111/ecca.12083

Stratton LS (2012) The role of preferences and opportunity costs in determining the time allocated to housework. Am Econ Rev 102(3):606-611. doi:10.1257/aer.102.3.606

Ueda A (2005) Intrafamily time allocation of housework: evidence from Japan. J Jpn Int Econ 19(1):1-23. doi:10.1016/j. jiiie.2003.12.002

Usui E (2008) Job satisfaction and the gender composition of jobs. Econ Lett 99(1):23-26. doi:10.1016/j.econlet.2007.05.019

Yeung WJ, Sandberg JF, Davis-Kean PE, Hofferth LS (2001) Children's time with fathers in intact families. J Marriage Fam 63(1):136-154. doi:10.1111/j.1741-3737.2001.00136.x

\section{Submit your manuscript to a SpringerOpen ${ }^{\circ}$ journal and benefit from:}

- Convenient online submission

- Rigorous peer review

- Immediate publication on acceptance

- Open access: articles freely available online

- High visibility within the field

- Retaining the copyright to your article

Submit your next manuscript at $\boldsymbol{~ s p r i n g e r o p e n . c o m ~}$ 